\title{
IDENTIFIKASI KEMURNIAN DAGING BERBASIS ANALISIS CITRA
}

\author{
Nila Susila Yulianti ${ }^{*}$, Kudang Boro Seminar ${ }^{2}$, Joko Hermanianto ${ }^{3}$, Sri Wahjuni ${ }^{4}$ \\ 1,4 Departemen Ilmu Komputer FMIPA IPB \\ ${ }^{2}$ Departemen Teknik Mesin \& Biosistem FATETA IPB, ${ }^{3}$ Departemen Ilmu dan Teknologi Pangan FATETA IPB \\ Email: ${ }^{1}$ nila_yulianti@apps.ipb.ac.id, ${ }^{2}$ seminarkudangboro@apps.ipb.ac.id, ${ }^{3}$ jokoher@apps.ipb.ac.id, \\ ${ }^{4}$ my_juni04@apps.ipb.ac.id \\ *Penulis Korespondensi
}

(Naskah masuk: 24 Februari 2020, diterima untuk diterbitkan: 19 Juli 2021)

\begin{abstract}
Abstrak
Daging sapi merupakan salah satu sumber protein hewani yang diperlukan oleh tubuh. Konsumsi daging sapi per kapita di tahun 2014 sebesar 2,52 $\mathrm{kg}$ dan terjadi penurunan pada tahun 2015 sebesar 2,31 kg yaitu 8,33 $\%$. Di tahun 2017, konsumsi daging sapi mengalami kenaikan sebesar 2,70 kg yaitu $16,88 \%$. Sementara harga rata-rata daging sapi di tahun 2015 sebesar Rp 104747 per kg dan mengalami kenaikan pada tahun 2016 yaitu 8,41\% sebesar Rp 113555 per kg. Di tahun 2017 kembali terjadi kenaikan yaitu 2,09\% sebesar 115932 per kg. Berdasarkan sensus penduduk tahun 2010 mendata jumlah penduduk muslim sebesar 207176162 yaitu $87 \%$ dari total penduduk di Indonesia. Kepastian daging halal sangat penting di negara mayoritas muslim. Metode secara konvensional dengan uji laboratorium untuk mendeteksi daging celeng membutuhkan waktu yang relatif lama, tempat khusus, serta biaya yang relatif mahal. Sementara daging yang diwaspadai dicampur dengan daging babi hutan bisa terjadi di berbagai tempat seperti pasar, retailer serta distributor yang sepatutnya bisa dideteksi seketika di tempat tersebut secara cepat. Oleh karena itu, diperlukan sistem yang mudah, cepat, dan mudah dibawa untuk mendeteksi daging sapi murni (tanpa campuran daging lainnya) dalam penelitian ini adalah daging celeng.

Penelitian ini membahas metode deteksi daging campuran berbasis citra menggunakan Convolutional Neural Network (CNN) yang dapat dioperasikan di android. Keunggulan metode ini dapat melakukan proses pembelajaran secara mandiri yaitu ekstraksi citra dan klasifikasi. Adapun kemampuan lain yang dimiliki yaitu dapat menangani deformasi gambar seperti rotasi dan skala. Akurasi yang didapatkan dari metode ini yaitu $94 \%$ untuk mendeteksi daging sapi murni, daging celeng murni, dan daging campuran sapi dan celeng. Sementara presisi untuk celeng, campuran dan sapi yaitu $100 \%, 90 \%$ dan $95 \%$. Selain itu, recall untuk celeng, campuran dan sapi yaitu $85 \%, 95 \%$, dan 97,5\%. Prototipe sistem deteksi yang dikembangkan telah diimplementasikan pada platform Android dan diuji pada situasi pencahayaan yang masih terkondisikan. Upaya penyempurnaan ke depan adalah menambah fitur sistem pencahayaan khusus/standar dengan kamera khusus yang memiliki cahaya tambahan yang mengatasi keragaman tingkat pencahayaan di tempat terbuka.
\end{abstract}

Kata kunci: aplikasi android, daging campuran, daging celeng, daging sapi, sistem cerdas.

\section{IDENTIFICATION OF MEAT PURITY BASED ON IMAGE ANALYSIS}

\begin{abstract}
Beef is one of animal protein source that important for human body. Beef consumption per capita in 2014 was $2.52 \mathrm{~kg}$ and it was decreasing in 2015 i.e., $2,31 \mathrm{~kg}$ by $8.33 \%$. In 2017, beef consumption has increased i.e., $2.70 \mathrm{~kg}$ by 16,88\%. While The average price of beef at Rp $104747 \mathrm{per} \mathrm{kg}$ in 2015 and went up by $8,41 \%$ at $\mathrm{Rp}$ 113555 per $\mathrm{kg}$ in 2016. In 2017, there was an increase by 2,09\% at Rp $115932 \mathrm{per} \mathrm{kg}$. The increase of beef price average occurred in 2015 amounting to Rp $104747 \mathrm{per} \mathrm{kg}$ and an increase in 2016 that was 8.41\% amounting to $\mathrm{Rp} 113555 \mathrm{per} \mathrm{kg}$. Based on the population census in 2010 recorded a Muslim population of 207176162 which is $87 \%$ of the total population in Indonesia. Halal (lawful) meat certainty is very critical in the muslim majority country. The conventional method with laboratory testing to detect wild boar meat requires a relatively long time, a special place, and a relatively expensive cost. While meat that is mixed with wild boar can happen in various places such as markets, retailers and distributors which can be detected immediately in that place quickly.Therefore, a system that can be easily, quickly and portably used for detecting pure beef (without other mixed meat) in this study is wild boar.

This research discusses image-based mixed meat detection methods using the Convolutional Neural Network (CNN) that can be operated on android device. so the proposed computationally method is Convolutional Neural Network (CNN). The advantages of this method can do the learning process
\end{abstract}


independently, object extraction and classification. While the other capabilities that can handle image deformation such as rotation and scale. This method yields an overall accuracy of $94 \%$ for detecting pure beef, pure wild boar meat, and mixed beef and wild boar. The obtained precision values for wild boar, mixed meat and beef are by $100 \%, 90 \%$ and $95 \%$ respectively. Moreover, the values recall for wild boar, mixed meat and beef are by $85 \%, 95 \%$ and 97,5\% respectively. The prototype detection system developed has been implemented on the Android platform and tested in conditioned lighting situation. A future effort to improve is providing special / standard lighting with a special camera that has additional light that can overcome the diversity of levels of exposure in the open areas.

Keywords: android application, mixed meat, wild boar, beef, smart system.

\section{PENDAHULUAN}

Daging sapi merupakan salah satu sumber protein hewani yang diperlukan oleh tubuh karena mempunyai kandungan zat besi, selenium, zinc, vitamin B kompleks, dan juga omega 3 (Arsy et al., 2016). Asupan gizi yang cukup dan baik salah satunya berasal daging sapi dapat mengurangi potensi stunting yaitu tinggi anak lebih rendah dibandingkan rata-rata tinggi ideal anak seusianya (DEPKES, 2018). Konsumsi daging sapi per kapita per tahun di tahun 2014 sebesar 2,52 kg dan terjadi penurunan pada tahun 2015 sebesar $2,31 \mathrm{~kg}$ yaitu $8,33 \%$. Di tahun 2017, konsumsi daging sapi mengalami kenaikan sebesar $2,70 \mathrm{~kg}$ yaitu $16,88 \%$ (BPS, 2017). Pada tahun 2015 harga rata-rata daging sapi sebesar Rp 104747 per $\mathrm{kg}$ dan mengalami peningkatan pada tahun 2016 yaitu 8,41\% sebesar Rp 113555 per kg. Di tahun 2017 kembali terjadi kenaikan harga yaitu 2,09\% sebesar 115932 per kg (DJPKH, 2018). Berdasarkan sensus penduduk 2010, jumlah penduduk muslim sebesar 207176162 yaitu $87 \%$ dari total penduduk di Indonesia (BPS, 2010). Kepastian daging halal sangat penting di negara mayoritas muslim. Sementara daging yang diwaspadai dicampur dengan daging babi hutan bisa terjadi di berbagai tempat seperti pasar, retailer serta distributor yang sepatutnya bisa dideteksi seketika di tempat tersebut secara cepat. Oleh karena itu, diperlukan sistem yang mudah, cepat, dan mudah dibawa untuk mendeteksi daging sapi murni (tanpa campuran daging lainnya yaitu daging celeng).

Pada penelitian Budianita et al., (2015) dilakukan pengolahan citra untuk membedakan daging sapi dan daging babi berdasarkan warna dan tekstur dengan metode Hue Saturation Value (HSV) dan Gray Level Co-Occurrence Matrix (GLCM) kemudian diklasifikasi menggunakan metode $K$ Nearest Neighbour yang didapatkan akurasi sebesar $88,75 \%$ tanpa background dan 73,4 \% dengan background. Pendeteksian berdasarkan tekstur dilakukan oleh Neneng et al., (2016) dengan metode Gray Level Co-Occurrence Matrix (GLCM) dan Support Vector Machine (SVM) dihasilkan akurasi sebesar 87,5\%. Handayani (2017) meneliti daging sapi, daging babi dan daging oplosan berdasarkan tekstur dengan metode gabor dan Probabilistic Neural Networks (PNN) diperoleh akurasi sebesar $57,14 \%$. Metode Histogram dan $K$ Means digunakan oleh Himawan dan Wiratama
(2018) untuk membedakan daging sapi dan daging babi berdasarkan tekstur didapatkan akurasi sebesar $65 \%$.

Metode secara konvensional dengan uji laboratorium untuk mendeteksi daging celeng membutuhkan waktu yang relatif lama dan biaya yang cukup mahal sehingga diusulkan metode secara komputasi dengan Convolutional Neural Network (CNN) untuk mengenali daging melalui citra. Keunggulan metode ini mampu melakukan ekstraksi citra dan klasifikasi dengan proses pembelajaran secara mandiri Arrofiqoh dan Harintaka (2018) selain itu juga dapat menangani deformasi gambar seperti translasi, rotasi dan skala (Zufar dan Setiyono, 2016). Untuk memudahkan penggunaan bagi masyarakat umum maka dibuat prototype aplikasi berbasis android. Pada masa depan diharapkan penelitian ini dapat memudahkan konsumen untuk mengenali daging yang akan dibeli terutama konsumen yang beragama muslim agar terhindar dari daging oplosan yang dijual di pasaran.

\section{METODE PENELITIAN}

\subsection{Convolutional Neural Network (CNN)}

Menurut Santoso dan Ariyanto (2018) Convolutional Neural Network adalah salah satu jenis neural network yang digunakan dalam pengolahan data image. Convolutional adalah matriks yang memiliki fungsi melakukan filter pada proses training. Proses training terdiri dari 3 tahapan yaitu convolutional layer, pooling layer, dan fully connected layer yang ditunjukkan pada Gambar 1 .

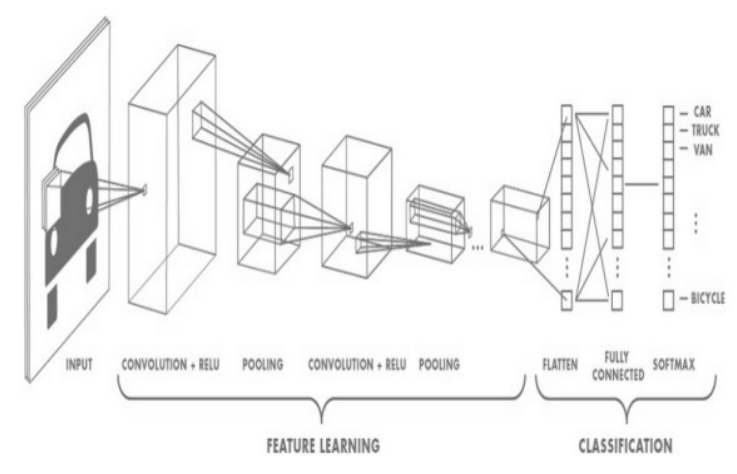

Gambar 1. Proses Convolutional Neural Network (Santoso dan Ariyanto, 2018) 
Convolutional Layer adalah lapisan untuk mengkonversi setiap filter ke seluruh bagian data masukan dan menghasilkan activation map atau feature map 2D. Tiap lapisan memiliki parameter yang dapat diubah, yaitu filter dan stride. Pada filter memiliki panjang, tinggi, dan tebal (depth). Sementara untuk stride, semakin kecil stride maka akan semakin detail informasi yang didapatkan dari input, namun membutuhkan komputasi yang lebih besar dibandingkan dengan stride yang lebih besar. Sebagai contoh pada Gambar 2, citra input berukuran 32 × 32 × 3 piksel. Sedangkan filter yang digunakan berukuran 5 × 5 × 3 piksel. Proses filter menghasilkan activation map berukuran $28 \times 28$ x 1 piksel. Setelah proses filter, kemudian dilakukan proses stride (penggeseran filter) secara vertikal dan horizontal sebanyak 1 atau 2 stride.

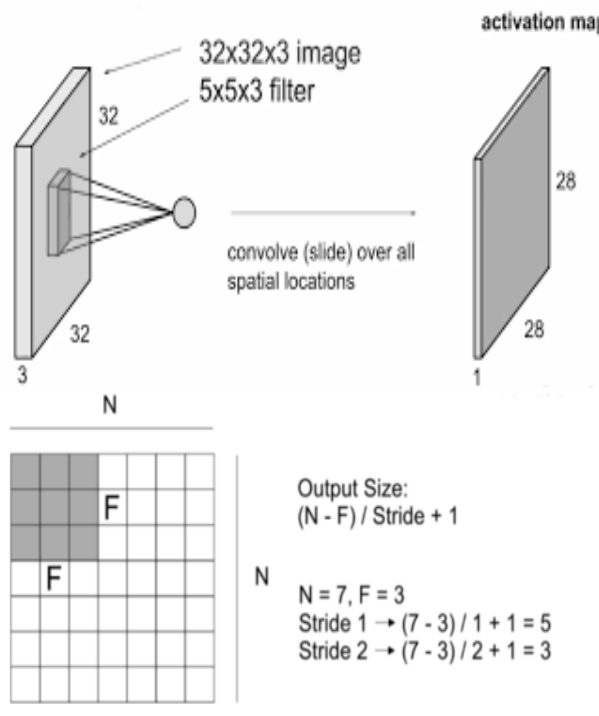

Gambar 2. Convolutional Layer

(Santoso dan Ariyanto, 2018)

Pooling Layer adalah tahap setelah convolutional layer yang setiap penggeseran ditentukan oleh jumlah stride pada seluruh area feature map atau activation map. Penerapan pooling layer bertujuan untuk mengurangi dimensi dari feature map sehingga mempercepat komputasi dan mengatasi overfitting (kondisi hampir semua data telah melalui proses training untuk mencapai persentase yang baik, tetapi yang terjadi ketidaksesuaian pada proses prediksi). Sebagai contoh, pada Gambar 3, menggunakan max pooling yaitu mencari nilai terbesar di antara matrik $2 \times 2$ dan penggeseran filter (stride) yaitu 2 piksel.

Fully Connected Layer adalah feature map dari pooling layer berbentuk multidimensional array yang melalui proses flatten atau reshape. Proses flatten menghasilkan sebuah vector yang digunakan sebagai input yang ditunjukkan pada Gambar 4.

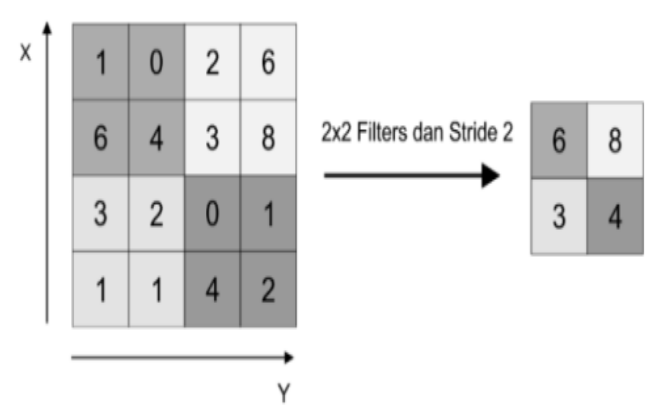

Gambar 3. Pooling Layer (Santoso dan Ariyanto, 2018)

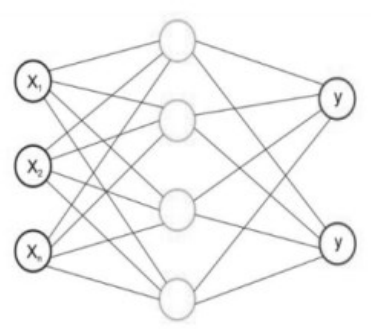

Keterangan :

$\mathrm{X}=$ Input Layer

$\mathrm{o}=$ Fully Connected Layer

$\mathrm{y}=$ Output Layer

Gambar 4. Fully Connected Layer

(Santoso dan Ariyanto, 2018)

\subsection{Library Keras}

Menurut Pangestu dan Bunyamin (2018) Keras adalah high level neural network API yang dapat dijalankan pada framework-framework machine learning seperti tensorflow, CNTK, atau theano yang ditulis dalam bahasa python dan menyediakan API yang mempermudah user dalam membangun arsitektur ANN (Artificial Neural Network). Selain itu, Keras juga menyediakan Keras Application yang merupakan deep learning models yang dijalankan bersama dengan pre-trained weights dimana modelmodel tersebut dapat digunakan untuk memprediksi dan melakukan feature extraction atau fine-tuning.

\subsection{Tensorflow}

Menurut Pangestu dan Bunyamin (2018) Tensorflow adalah framework machine learning yang bekerja dalam skala besar dan mempunyai environment yang heterogeneous yang digunakan untuk melakukan eksperimen model deep learning, melatih model pada dataset yang berukuran besar dan juga mendukung training dan inference berskala besar dengan menggunakan ratusan server yang menggunakan GPU (Graphic Processing Unit). Penelitian ini menggunakan Tensorflow sebagai backend framework untuk Keras. 


\subsection{Confusion Matrix}

Menurut Liu (2008) Confusion matrix adalah suatu metode klasifikasi yang berisi informasi tentang hasil actual dan hasil prediksi. Kelas yang diminati disebut kelas positif sedangkan kelas negative digabung menjadi satu kelas negatif. Tabel confusion matrix dapat dilihat pada Tabel 1.

Tabel 1. Confusion Matrix

\begin{tabular}{lcc}
\hline & Classified positive & Classified negative \\
\hline $\begin{array}{l}\text { Actual } \\
\text { positive } \\
\begin{array}{l}\text { Actual } \\
\text { negative }\end{array}\end{array}$ & TP & FN \\
\hline
\end{tabular}

Keterangan tabel Confusion Matrix di atas :

a. True Positives (TP) adalah jumlah klasifikasi contoh positif yang benar

b. False Positives (FP) adalah jumlah klasifikasi contoh negatif yang salah

c. False Negatives (FN) adalah jumlah klasifikasi contoh positif yang salah

d. True Negatives (TN) adalah jumlah klasifikasi contoh negatif yang benar

Akurasi dihitung dengan persamaan 1 sebagai berikut : (Cichosz, 2015).

akurasi $=(\mathrm{TP}+\mathrm{TN}) /(\mathrm{TP}+\mathrm{TN}+\mathrm{FP}+\mathrm{FN})$

Presisi dan recall dihitung dengan persamaan 2 dan 3 sebagai berikut : (Liu, 2008).

presisi $=\mathrm{TP} /(\mathrm{TP}+\mathrm{FP})$

recall $=\mathrm{TP} /(\mathrm{TP}+\mathrm{FN})$

Menurut Chichosz (2015) akurasi adalah rasio sampel yang diklasifikasikan dengan benar untuk semua sampel. Sementara pada presisi adalah rasio sampel dengan benar diklasifikasikan sebagai positif terhadap semua sampel yang diklasifikasikan sebagai positif dan recall adalah sampel yang diklasifikasikan benar positif. dan recall untuk menunjukkan jumlah data yang diklasifikasikan secara benar.

\section{HASIL DAN PEMBAHASAN}

\subsection{Akuisisi Data}

Akuisisi dilakukan dengan mencampur daging menggunakan 3 ember yaitu ember pertama untuk mengaduk daging sapi, ember kedua untuk mengaduk daging celeng, dan ember yang ketiga untuk mengaduk campuran daging sapi dengan daging celeng. Pengambilan citra dari kamera smartphone dengan ukuran piksel 3120 x 3120 yang menghasilkan gambar sebanyak 500 citra, kemudian membagi data menjadi 2 yaitu data training sebanyak $80 \%$ dan data testing sebanyak $20 \%$ yang mendapatkan 400 citra untuk data training dan 100 citra untuk data testing.

\subsection{Membangun Model CNN}

\subsubsection{Praproses Data}

Setelah dilakukan tahap akuisisi, praproses citra dilakukan dengan tujuan untuk mempercepat waktu pengolahan citra. Praproses data daging dengan mengubah ukuran citra dari 3120 x 3120 piksel menjadi 64 x 64 piksel. Citra yang digunakan masih mempunyai background dan belum dilakukan proses cropping. Hasil praproses seperti pada Gambar 5.

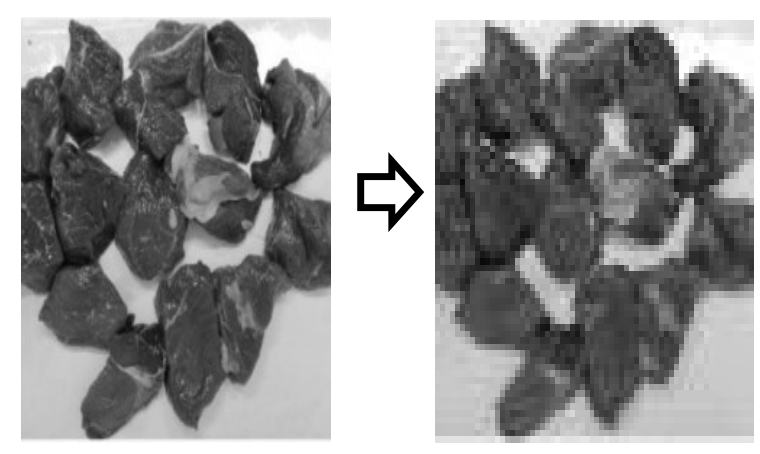

Gambar 5. Hasil Praproses Data

\subsubsection{Pemilihan Parameter Model CNN}

Sebelum dilakukan pemilihan parameter data training untuk membangun model $\mathrm{CNN}$ ada tiga tahapan proses yaitu convolutional layer, pooling layer, dan fully connected layer. Tahapan pertama, convolutional layer digunakan feature map dengan filter panjang, tinggi, dan tebal (depth) \(8itu $3 \times 3 \times$ 3 dengan penggeseran filter (stride) sebanyak 1 piksel. Tahapan kedua, pooling layer mencari nilai terbesar (max pooling) pada matrik berukuran $2 \times 2$ dan stride yang digunakan yaitu 2 piksel. Tahapan ketiga, fully connected layer dilakukan flatten dengan 128 hidden layer.

\subsubsection{Pemilihan Parameter Data Training}

Data training yang digunakan sebanyak 400 citra. Parameter yang akan diamati berdasarkan learning rate dan epoch. Pembagian data training dapat dilihat pada Tabel 2.

Tabel 2. Pembagian Data Training

\begin{tabular}{lcc}
\hline \multicolumn{1}{c}{ Kelas } & Jumlah Gambar & \\
\hline Celeng & 80 \\
\hline Campuran & 160 \\
\hline Sapi & 160 \\
\hline Total Gambar & 400 \\
\hline
\end{tabular}

Pada penelitian Liu (2018) $k$-fold merupakan metode untuk mempartisi data yang tersedia menjadi $\mathrm{k}$ subset dengan ukuran yang sama. Setiap subset digunakan sebagai set pengujian dan sisa himpunan 
k-1 digabungkan sebagai set pelatihan untuk mempelajari pengklasifikasi. Kinerja model pada penelitian ini dievaluasi menggunakan 10 fold yang membagi data sampel secara acak dan mengelompokkan data sebanyak 10 fold, kemudian salah satu kelompok 10 fold akan dijadikan data uji dan sisa kelompok lainnya dijadikan data latih (Sianturi et al., 2018). Pelatihan menggunakan learning rate $0.01,0.05,0.1,0.25,0.5$ dengan iterasi 30 dan image size 64 mendapatkan model CNN dengan akurasi terbaik pada learning rate 0.01 yang menghasilkan akurasi rata-rata sebesar 99,75\%. Evaluasi dan hasil prediksi model dapat dilihat pada Tabel 3 dan 4.

Tabel 3. Evaluasi Model

\begin{tabular}{|c|c|c|c|c|c|}
\hline \multicolumn{6}{|c|}{ Epoch : 30 dan Image Size : 64} \\
\hline \multirow[b]{2}{*}{$\mathbf{K}$} & \multicolumn{5}{|c|}{ Learning Rate } \\
\hline & $\mathbf{0 . 0 1}$ & 0.05 & 0.1 & 0.25 & 0.5 \\
\hline 1 & $97,5 \%$ & $90 \%$ & $97 \%$ & $97 \%$ & $95 \%$ \\
\hline 2 & $100 \%$ & $100 \%$ & $100 \%$ & $100 \%$ & $100 \%$ \\
\hline 3 & $100 \%$ & $100 \%$ & $100 \%$ & $100 \%$ & $100 \%$ \\
\hline 4 & $100 \%$ & $100 \%$ & $100 \%$ & $100 \%$ & $100 \%$ \\
\hline 5 & $100 \%$ & $100 \%$ & $100 \%$ & $100 \%$ & $100 \%$ \\
\hline 6 & $100 \%$ & $100 \%$ & $100 \%$ & $100 \%$ & $100 \%$ \\
\hline 7 & $100 \%$ & $100 \%$ & $100 \%$ & $100 \%$ & $100 \%$ \\
\hline 8 & $100 \%$ & $100 \%$ & $100 \%$ & $100 \%$ & $100 \%$ \\
\hline 9 & $100 \%$ & $100 \%$ & $100 \%$ & $100 \%$ & $100 \%$ \\
\hline 10 & $100 \%$ & $100 \%$ & $100 \%$ & $100 \%$ & $100 \%$ \\
\hline $\begin{array}{l}\text { Akurasi } \\
\text { rata-rata }\end{array}$ & $99,75 \%$ & $99 \%$ & $99,7 \%$ & $99,7 \%$ & $99,5 \%$ \\
\hline
\end{tabular}

Tabel 4. Hasil Prediksi Model dengan Confusion Matrix

\begin{tabular}{crrr}
\hline & \multicolumn{3}{c}{ Prediksi } \\
\hline Aktual & Celeng & Campuran & Sapi \\
& & & 0 \\
\hline Celeng & 80 & 160 & 0 \\
\hline Campuran & 0 & 0 & 160 \\
\hline Sapi & 0 & & \\
\hline
\end{tabular}

Tabel 5. Akurasi, Presisi dan Recall Data Training

\begin{tabular}{|c|c|c|}
\hline & Kelas & \\
\hline & Celeng Campuran & Sapi \\
\hline Akurasi & $100 \%$ & \\
\hline Presisi & $100 \%$ & \\
\hline Recall & $100 \%$ & \\
\hline
\end{tabular}

Akurasi yang didapatkan dari data training yaitu sebesar $100 \%$ dibuktikan dengan tabel confusion matrix bahwa model dapat membaca gambar secara tepat sesuai jumlah data tiap kelas. Presisi celeng, campuran dan sapi yang didapatkan sebesar $100 \%$ ini membuktikan bahwa tidak ada kelas bukan celeng diprediksikan sebagai celeng sedangkan presisi campuran membuktikan bahwa tidak ada kelas bukan campuran diprediksikan sebagai campuran dan presisi sapi membuktikan bahwa tidak ada kelas bukan sapi diprediksikan sebagai sapi. Pada recall celeng, campuran dan sapi yang didapatkan sebesar $100 \%$ ini membuktikan bahwa tidak ada kelas celeng diprediksikan sebagai bukan celeng. Sedangkan recall campuran membuktikan bahwa tidak ada kelas campuran diprediksikan sebagai bukan campuran dan presisi sapi membuktikan bahwa tidak ada kelas sapi diprediksikan sebagai bukan sapi.

\subsubsection{Validasi Parameter Model CNN}

Parameter Model CNN terbaik yang didapatkan pada image size 64, learning rate (LR) 0.01 dan 30 iterasi, selanjutnya akan dilakukan validasi pada data testing sebanyak 100 citra dan pengujian akurasi model menggunakan confusion matrix. Pengujian ini menghasilkan akurasi sebesar $94 \%$. Pembagian data testing dan hasil prediksi data testing dapat dilihat pada Tabel 6 dan 7 .

Tabel 6. Pembagian Data Testing

\begin{tabular}{lr}
\hline \multicolumn{1}{c}{ Kelas } & Jumlah Gambar \\
\hline Celeng & 20 \\
\hline Campuran & 40 \\
\hline Sapi & 40 \\
\hline Total Gambar & 100 \\
\hline
\end{tabular}

Tabel 7. Hasil Prediksi Data Testing dengan Confusion Matrix

\begin{tabular}{crrr}
\hline & \multicolumn{3}{c}{ Prediksi } \\
\hline Aktual & Celeng & Campuran & \multicolumn{1}{c}{ Sapi } \\
& & 3 & 0 \\
\hline Celeng & 17 & 38 & 2 \\
\hline Campuran & 0 & 1 & 39 \\
\hline Sapi & 0 & & \\
\hline
\end{tabular}

Tabel 8. Akurasi, Presisi dan Recall Data Testing

\begin{tabular}{crrr}
\hline & \multicolumn{3}{c}{ Kelas } \\
& Celeng & Campuran & \multicolumn{1}{c}{ Sapi } \\
\hline \multicolumn{3}{c}{$94 \%$} \\
\hline Pkurasi & $90 \%$ \% & $95 \%$ \\
\hline Recall & $85 \%$ & $95 \%$ & $97,5 \%$ \\
\hline
\end{tabular}

Akurasi yang dihasilkan dari data testing yaitu sebesar $94 \%$ yang dibuktikan dengan Tabel 8 dan dihitung dengan persamaan (1) bahwa masih ada kesalahan prediksi yaitu data sebenarnya atau data aktual diprediksi tidak sesuai pada kelasnya. Presisi dihitung dengan persamaan (2), untuk presisi celeng didapatkan sebesar $100 \%$ bahwa tidak ada kelas bukan celeng diprediksikan sebagai celeng. Sedangkan presisi campuran didapatkan sebesar 90 
\% yang mana masih ada 4 data kelas bukan campuran diprediksikan sebagai campuran dan presisi sapi didapatkan sebesar $95 \%$ yang mana masih ada 1 data kelas bukan sapi diprediksikan sebagai sapi. Recall dihitung dengan persamaan (3), recall celeng didapatkan sebesar $85 \%$ yang mana masih ada 3 data kelas celeng diprediksikan sebagai bukan celeng. Sedangkan recall campuran didapatkan sebesar $95 \%$ yang mana masih ada 2 data kelas campuran diprediksikan sebagai bukan campuran dan recall sapi didapatkan sebesar 97,5\% yang mana masih ada 1 data kelas sapi diprediksikan sebagai bukan sapi. Suatu model dapat dikatakan baik jika hasil akurasi, presisi dan recall memiliki nilai yang tinggi, akan tetapi jika salah satu parameter rendah maka akan menimbulkan bias atau kesalahan dari suatu nilai. Akurasi, presisi dan recall diukur dengan confusion matrix yang menunjukkan hasil prediksi memiliki tingkat kesalahan yang rendah dan ini artinya model yang dihasilkan mempunyai konsistensi dalam melakukan klasifikasi gambar.

\subsection{Implementasi}

Model CNN yang sudah dibuat diimplementasikan pada smartphone android dengan menggunakan IDE Android Studio. Aplikasi ini menggunakan jaringan server IPB yang sebelumnya sudah diinstal XAMPP, Python, OpenCV, Numpy dan Keras. Pada tahap selanjutnya, untuk memasukkan model ke dalam server diperlukan software WinSCP agar terkoneksi jaringan secara lokal IPB. Setelah model diupload dilakukan setting server agar model yang dimasukkan dapat aktif untuk digunakan. Aplikasi ini memiliki tiga menu utama yaitu cek galeri, ambil foto dan prediksi daging. Menu cek galeri digunakan untuk mengambil gambar daging dari galeri smartphone, untuk menu ambil foto untu menangkap objek daging secara langsung dari kamera smartphone, dan pada menu prediksi daging untuk mengenali objek daging yang sudah ditangkap oleh kamera.

\subsection{Pengujian Aplikasi}

Pengujian aplikasi dilakukan dengan black box, hal ini bertujuan untuk mengurangi jumlah uji coba yang membutuhkan eksekusi tanpa mengurangi ruang lingkup pengujian (Homes, 2019). Ada tiga menu yang diuji yaitu ambil foto, cek galeri dan prediksi daging, hasil pengujian pada Tabel 9 menunjukkan bahwa output sesuai dengan yang diharapkan. Selain itu, pengujian daging dengan aplikasi Android menggunakan citra dari data testing yang menunjukkan bahwa hasil prediksi sesuai dengan label pada daging. Hasil prediksi dapat dilihat pada Gambar 6.
Tabel 9. Pengujian Aplikasi dengan Black Box

\begin{tabular}{|c|c|c|c|}
\hline $\begin{array}{c}\text { Nama } \\
\text { Pengujian }\end{array}$ & $\begin{array}{c}\text { Bentuk } \\
\text { Pengujian }\end{array}$ & $\begin{array}{l}\text { Hasil yang } \\
\text { Diharapkan }\end{array}$ & $\begin{array}{c}\text { Hasil } \\
\text { Pengujian }\end{array}$ \\
\hline $\begin{array}{l}\text { Menu Ambil } \\
\text { Foto }\end{array}$ & $\begin{array}{c}\text { Menekan } \\
\text { Tombol } \\
\text { Ambil Foto }\end{array}$ & $\begin{array}{c}\text { Membuka } \\
\text { Kamera }\end{array}$ & Berhasil \\
\hline $\begin{array}{c}\text { Menu Cek } \\
\text { Galeri }\end{array}$ & $\begin{array}{c}\text { Menekan } \\
\text { Tombol Cek } \\
\text { Galeri }\end{array}$ & $\begin{array}{c}\text { Membuka } \\
\text { Galeri Foto }\end{array}$ & Berhasil \\
\hline $\begin{array}{c}\text { Menu Prediksi } \\
\text { Daging }\end{array}$ & $\begin{array}{c}\text { Menekan } \\
\text { Tombol } \\
\text { Prediksi } \\
\text { Daging }\end{array}$ & $\begin{array}{c}\text { Muncul } \\
\text { Pesan } \\
\text { Gambar } \\
\text { Kosong! } \\
\text { Mohon } \\
\text { Masukkan } \\
\text { Gambar } \\
\text { Melalui } \\
\text { Tombol } \\
\text { "Cek Galeri” } \\
\text { atau "Ambil } \\
\text { Foto" }\end{array}$ & Berhasil \\
\hline
\end{tabular}
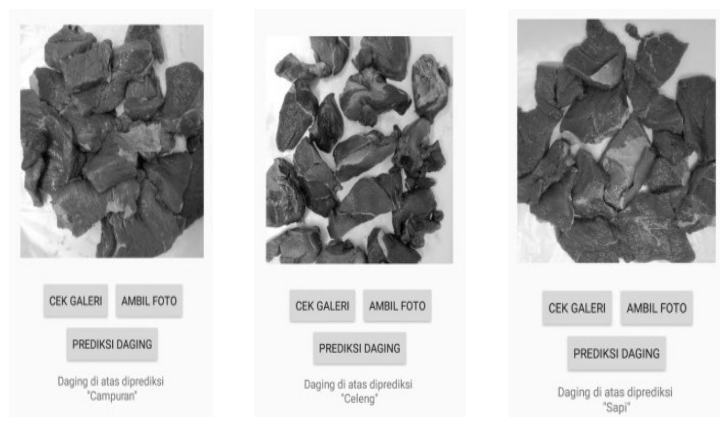

Gambar 6. Hasil Pengujian Daging

\subsection{Evaluasi}

Pada tanggal 11 Desember 2019, peneliti bekerjasama dengan LPPOM MUI Bogor untuk melakukan tes Pork Detection Kit (PDK), yang menggunakan sampel daging dalam kondisi segar dari Pasar Anyar Bogor. Hasil tes didapatkan pada tanggal 30 desember 2019 dengan nomor sertifikat No. AS42/LAB/LPPOM MUI/XII/2019 bahwa tidak terdeteksi babi hutan. Sebelumnya dilakukan pengujian aplikasi dan hasil prediksi aplikasi adalah sapi maka dapat disimpulkan bahwa hasil prediksi aplikasi sudah tepat. Perlakuan atau kondisi untuk pengambilan gambar sangat mempengaruhi hasil prediksi untuk itu pada tahap akuisisi data perlu memperhatikan warna background dan cara melakukan pemotongan daging agar dapat diprediksi secara tepat. Hasil prediksi daging dapat dilihat pada Gambar 7. 


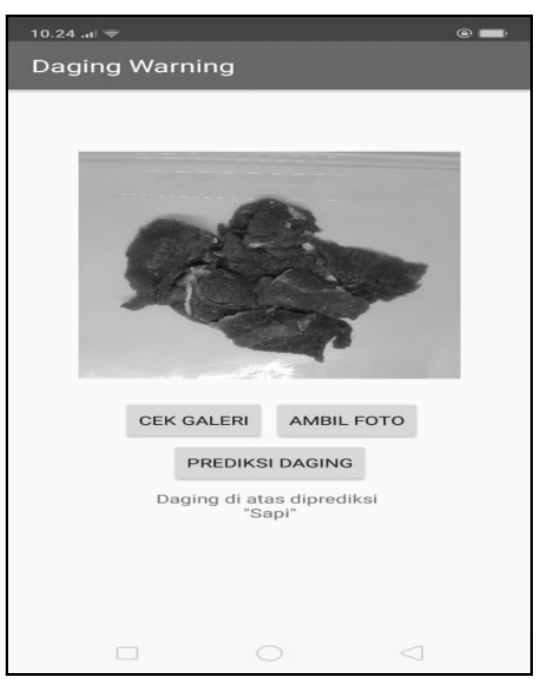

Gambar 7. Hasil Prediksi Aplikasi

\section{KESIMPULAN}

Penelitian ini menghasilkan akurasi pada data training sebesar $100 \%$ dan akurasi pada data testing sebesar $94 \%$ dengan presisi untuk celeng sebesar $100 \%$, presisi untuk campuran sebesar $90 \%$ dan presisi untuk sapi sebesar $95 \%$ sedangkan recall yang didapatkan untuk celeng sebesar $85 \%$, recall untuk campuran sebesar $95 \%$ dan recall untuk sapi sebesar 97,5\%, dapat disimpulkan CNN mampu mengindentifikasi daging sapi murni tanpa campuran daging celeng.

\section{UCAPAN TERIMA KASIH}

Banyak pihak yang telah membantu penulis dalam menyelesaikan penelitian ini. Penulis mengucapkan terima kasih kepada LPPOM MUI yang telah membantu dalam pengujian sampel daging. Ucapan terima kasih juga penulis berikan kepada Kementerian Riset, Teknologi dan Pendidikan Tinggi yang telah memberikan Beasiswa PasTi kepada penulis selama menempuh studi S2 di IPB.

\section{DAFTAR PUSTAKA}

ARROFIQOH EN, HARINTAKA. 2018. Implementasi Metode Convolutional Neural Network Untuk Klasifikasi Tanaman Pada Citra Resolusi Tinggi. Jurnal Geomatika, [e-journal] 24(2). Tersedia melalui: < $<$ http://jurnal.big.go.id/index.php/GM/article/vie w/810/810 $>$ [Diakses 11 April 2020]

ARSY L, NURHAYATI OD, MARTONO TK. 2016. Aplikasi Pengolahan Citra Digital Meat Detection Dengan Metode Segmentasi K-Mean Clustering Berbasis OpenCV Dan Eclipse. Jurnal Teknologi dan Sistem Komputer, [e-journal] 4(2). Tersedia melalui: $<$ https://jtsiskom.undip.ac.id/index.php/jtsiskom/ article/view/12719/12335> [Diakses 11 April 2020]

BPMSPH, 2018. Cara Pintar Pilih Pangan Asal Hewan. [ebook]. Balai Pengujian Mutu dan Sertifikasi Produk Hewan. Tersedia melalui: $<$ http://bpmsph.org/download/buku-pintar/> [Diakses 4 Maret 2019]

BPS. 2010. Hasil Sensus Penduduk 2010. Badan Pusat Statistik, [online] Tersedia di: $<$ https://sp2010.bps.go.id/> [Diakses 4 Februari 2020]

BPS. 2017. Kajian Konsumsi Bahan Pokok 2017. Badan Pusat Statistik, [online] Tersedia di: $<$ https://bps.go.id/ $>$ [Diakses 12 Maret 2020]

BUDIANITA E, JASRIL, HANDAYANI L. 2015. Implementasi Pengolahan Citra dan Klasifikasi K-Nearest Neighbour untuk Membangun Aplikasi Pembeda Daging Sapi dan Babi. Jurnal Sains, Teknologi, dan Industri, [e-journal] 12(2). Tersedia melalui: <http://ejournal.uinsuska.ac.id/index.php/sitekin/article/view/1005/1 009> [Diakses 11 April 2020]

CICHOSZ P. 2015. Data Mining Algorithms, [online] Tersedia di $<$ https://www.wiley.com/enus/Data+Mining+Algorithms\%3A+Explained $+\mathrm{U}$

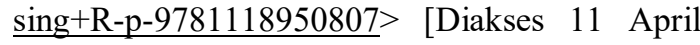
2020]

DEPKES. 2018. Ini Penyebab Stunting pada Anak. Departemen Kesehatan, [online] Tersedia di: $<$ http://www.depkes.go.id/article/view/18052800 006/ini-penyebab-stunting-pada-anak.html > [Diakses 24 Mei 2018]

DJPKN. 2018. Statistik Peternakan dan Kesehatan Hewan 2018. Direktorat Jenderal Peternakan dan Kesehatan Hewan, [online] Tersedia di: $<$ http://ditjenpkh.pertanian.go.id/userfiles/File/B uku_Statistik_2018 -

Final_ebook.pdf?time $=1543210844103>$

[Diakses 27 Januari 2019]

GODIL A, BOSTELMAN R, SHACKLEFORD W, HONG T, SHNEIER M. 2014. Performance Metrics for Evaluating Object and Human Detection and Tracking Systems. NISTIR 7972 National Institute of Standards and Technology Gaithersburg MD USA. [online] Tersedia di: < https://www.nist.gov/publications/performancemetrics-evaluating-object-and-human-detectionand-tracking-systems $>$ [Diakses 11 April 2020]

HANDAYANI L. 2017. Analisa Metode Gabor dan Propbabilistic Neural Network untuk Klasifikasi Citra. Jurnal Sains, Teknologi, dan Industri, [ejournal] 14(2). Tersedia melalui: < http://ejournal.uinsuska.ac.id/index.php/sitekin/article/view/3707/p df $>$ [Diakses 11 April 2020]

He Y, ZENG H, FAN Y, JI S, WU J. 2019. Application of Deep Learning in Integrated Pest Management : a Real-Time System for Detection and Diagnosis of Oilseed Rape Pests. Mobile Information System. [online] Tersedia di: $<$ 
https://www.hindawi.com/journals/misy/2019/45 70808/> [Diakses 11 April 2020]

HIMAWAN H, WIRATAMA W. 2018. Different Types of Beef and Pork Using Histogram Texture and K-Means Clustering Method. Journal of Applied Intelligent System, [e-journal] 3(1). Tersedia melalui: $<$ http://publikasi.dinus.ac.id/index.php/jais/articl e/view/1892/1323> [Diakses 11 April 2020]

HOMES B. 2012. Fundamentals of Software Testing, [online] Tersedia di $<$ https://www.wiley.com/enus/Fundamentals + of + Software+Testing-p-9781848213241 > [Diakses 11 April 2020]

LIU B. 2008. Web Data Mining: Exploring, Hyperlinks, Contents, and Usage Data, [online] Tersedia $<$ https://www.springer.com/gp/book/978364219 $\underline{4597>}$ [Diakses 11 April 2020]

NENENG, ADI K, ISNANTO RR. 2016. Support Vector Machine Untuk Klasifikasi Citra Jenis Daging Berdasarkan Tekstur Menggunakan Ekstraksi Ciri Gray Level Co-Occurrence Matrices (GLCM). Jurnal Sistem Informasi Bisnis, [e-journal] 6(1). Tersedia melalui: $<$ https://ejournal.undip.ac.id/index.php/jsinbis/ar ticle/view/10510/pdf> [Diakses 11 April 2020]

PANGESTU MA, BUNYAMIN H. 2018. Analisis Performa dan Pengembangan Sistem Deteksi Ras Anjing pada Gambar dengan Menggunakan PreTrained CNN Model. Jurnal Teknik Informatika dan Sistem Informasi, [e-journal] 4(2). Tersedia melalui:

https://journal.maranatha.edu/index.php/jutisi/art icle/view/1501/1172 [Diakses 11 April 2020]

SANTOSO A, ARIYANTO G. 2018. Implementasi Deep Learning Berbasis Keras Untuk Pengenalan Wajah. Jurnal Emitor, [e-journal] 18(1). Tersedia melalui: $<$ http://journals.ums.ac.id/index.php/emitor/articl e/view/6235/3901> [Diakses 11 April 2020]

SASONGKO TB. 2016. Komparasi dan Analisis Kinerja Model Algoritma SVM dan PSO -SVM (Studi Kasus Klasifikasi Jalur Minat SMA. Jurnal Teknik Informatika dan Sistem Informasi, [e-journal] 2(2). Tersedia melalui: $<$ http://jutisi.maranatha.edu/index.php/jutisi/artic le/view/476/424> [Diakses 11 April 2020]

SIANTURI TA, FURQON MT, INDRIATI. 2018. Penerapan Algoritme Fuzzy K-Nearest Neighbour Pada Pengklasifikasian Penyakit Kejiwaan Skizofrenia. Jurnal Pengembangan Teknologi Informasi dan Ilmu Komputer, [ejournal] 2(10), Tersedia melalui:

$<$ http://j-ptiik.ub.ac.id/index.php/jptiik/article/view/2646/990> [Diakses 11 April 2020]

ZUFAR M, SETIYONO B. 2016. Convolutional Neural Networks untuk Pengenalan Wajah Secara Real-Time. Jurnal Sains dan Seni ITS, [e- journal] 5(2). Tersedia melalui: $<\underline{\text { http://repository.its.ac.id/72552/> [Diakses } 11}$ April 2020] 